DOI: $10.20472 / S S .2019 .8 .1 .005$

\title{
MANIFESTATION OF ORGANIZATIONAL FACTORS ENGAGING PERSONNEL (IMPLEMENTING DISEASE PREVENTION PROGRAMS) IN WORK
}

\author{
DANUTE SIMKUTE, AUSRA KAZLAUSKIENE
}

\begin{abstract}
:
Healthcare institutions perform a delegated function which is to react to constantly occurring challenges and seek sustainable solutions. Meeting the mentioned challenges related to provision of services, it becomes important to retain employees. In this context, it becomes highly relevant to support personnel engagement in work at healthcare institutions because it stimulates employees' behavior which determines effectiveness of organization's performance and opens broader possibilities for personnel management. The present-day conditions of economy, value transformation, progress of new technologies, techniques lead to seek the ways to engage personnel in work. Organizational factors are treated as one of key factors impacting personnel engagement. By applying the survey and in-depth interview methods, the research presents manifestation of organizational factors in healthcare organizations implementing disease prevention programs.
\end{abstract}

\section{Keywords:}

organizational management, quality of organizational performance, personnel engagement in performance.

JEL Classification: M12

\section{Authors:}

DANUTE SIMKUTE, Siauliai University, Lithuania, Email: akantija@gmail.com AUSRA KAZLAUSKIENE, Siauliai University, Lithuania, Email: akazlauskiene@yahoo.com

\section{Citation:}

DANUTE SIMKUTE, AUSRA KAZLAUSKIENE (2019). MANIFESTATION OF ORGANIZATIONAL FACTORS ENGAGING PERSONNEL (IMPLEMENTING DISEASE PREVENTION PROGRAMS) IN WORK. International Journal of Social Sciences, Vol. VIII(1), pp. 55-67., 10.20472/SS.2019.8.1.005 


\section{Introduction}

Since the healthcare sector represents the public interest, especially high requirements related to assurance of sustainability of healthcare systems are set. In the Lithuania's Progress Strategy "Lithuania 2030", one of the objectives is directed to the public sector which is delegated to provide quality and relevant services to society making them closer to an individual through result-oriented performance. Healthcare institutions perform a delegated function which is to react to constantly occurring challenges and seek sustainable solutions (Law on Public Health Care of the Republic of Lithuania, 2002). However, healthcare institutions face another problem which is the lack of health care specialists (Taljunaite, 2012; On Effective, Accessible and Resilient Health Systems..., 2014; Green Paper on the European Workforce for Health, 2008). Thus, the institutions under discussion need not only to effectively meet occurring new challenges related to provision of services but also to retain employees. In this context, it becomes highly relevant to support personnel engagement in work at healthcare institutions because it stimulates employees' behavior which determines effectiveness of organization's performance and opens broader possibilities for personnel management (Zaptorius, 2007; Demyen, Popa, 2015). The present-day conditions of economy, value transformation, progress of new technologies, techniques lead to seek the ways to engage personnel in work. Organizational factors are treated as one of key factors impacting personnel engagement (Johnson, 2017; Peter C. Olden, 2011; Ledlow, Stephens, 2017; Burns, Bradley, Weiner, 2011; Miner, 2010; Karnieli-Miller, Taylor, Inui, Ivy, Frankel, 2011).

Organizational factors are considered in various research studies in different ways. Sharma, Bhati (2017), Yazani, Yaghoubi (2011) in their research mention the factors of open-communication, sharing the responsibilities, owning of the organizational outcomes, assurance of self-continuity, independence/ autonomy, provision of support; whereas Lambrou, Kontodimopoulos, Niakas (2010) emphasize importance of acknowledgement by top managers and colleagues, stable work/ income and learning. The factors of organizational learning culture and supportive leadership factors (Naqvi, Hashmi, Raza, Zeeshan, Shaikh, 2011; Ismail, Ford, 2009; Yang, 2006; Manongi, Marchant, Bygbjerg, 2006; Hejduková, Kureková, 2017) as well recognition and empowerment of employees (Manzoor, 2012) are frequently mentioned. Scientists (Byrne, 2006; Benson, Dundis, 2003; Kontodimopoulos, Paleologou, Niakas, 2009; Manongi, Marchant, Bygbjerg, 2006) suggest recognition of efforts of the medical staff, financial incentive means and improvement of performance (provision of facilities, suitable timetable) as strategic commitments of medical institutions. By mentioning the factors of self-efficiency of medical personnel, pride in their work, scientists (Franco, Bennett, Kanfer, Stubblebine, 2004; Laubach, Fischbeck, 2007) reject the need for financial incentive as a factor of engagement. To sum up the discussed investigations, we can have it that engagement of medical personnel in work is influenced by both financial and non-financial organizational factors. Organizational factors contributing to personnel engagement in work increase job satisfaction, and obtained knowledge allows implementing purposeful strategies for continuous development inside organization (Unterweger, Imhof, Mohr, Römpler, Kubik-Huch, 2007). To allow organizations perfect their strategies or design integrated systems for personnel engagement in work, it should be analyzed how organizational factors manifest in organization. In this context, the research problem is raised in relation to manifestation of organizational factors engaging health care personnel in work. 


\section{RESEARCH METHODOLOGY}

The structured survey in a written form provided the conditions for the investigation to assess distribution of employees' opinions, the dominating factors impacting engagement in work. The purpose of the chosen method was to obtain as objective information as possible and to retain impartiality of the researcher (Ritchie, Lewis, 2003). The questionnaire was anonymous. Aiming to obtain as objective and detailed research results as possible, the questionnaire comprised closed-type questions. The questionnaire briefly introduced the purpose of the research.

The research sample: 74 medical staff members (35 physicians, 39 nurses) who implement prevention programs. The informants have been selected by applying the method of random selection.

The survey presented 8 organizational factors (provision of opportunities for self-continuation, assessment of personal performance, financial stimulation, provision of favorable work conditions, provision of facilities for work, flexible timetable, optimal workload, assurance of autonomy), which motivate employees the most. Employees had to rate the given factors ( 1 - the most important, 8 - the least important). The listed eight organizational factors have been selected with regard to the most frequently referred dominating factors discussed in research works.

The analysis of the written survey employed mathematical statistical analysis applying the Pareto principle (Koch, 2011), which provided the possibilities to assess distribution of employees' opinions. Scholarly literature displays this principle by various titles: the Pareto principle, the $80 / 20$ rule, the principle of the least effort, the law of predictable imbalance. This principle can be characterized as a key to proper practical manifestation of efficiency in many fields of activities, including the search for the factors impacting personnel engagement in work. The applied Pareto principle has it that in majority of events 80 percent of the effects come from 20 percent of causes. In this case, 2 most dominating factors (comprising 20 percent and they will be treated as major causes determining personnel engagement in work) have been singled out of the 8 factors.

The method of in-depth interview provided the possibilities to assess the manifestation of the most dominating factors (to engage in work) selected by employees. Moreover, it is sought to reveal employees' opinions on possibilities to improve engagement in work. The in-depth interview approach has been chosen due to the following reasons (Ritchie, Lewis, 2003):

- to adjust the structure and resilience, i.e. that the topics would be discussed in a way which is the most suitable for an informant;

- to keep the interview as interactive as possible, i.e. the content is being generated through an interaction between researcher and respondent. The researcher formulates a question in a way to encourage a respondent to answer a question while fluently speaking;

- the researcher could use various techniques for investigation and in-depth analysis seeking depth of the responses, i.e. if the primary answer is "shallow", the researcher will use additional questions to deeper and broader perceive the meanings expressed by a respondent.

Arrangement of the investigation involved the following main stages: presentation of the research, start of the interview, process of the interview, end of the interview, process after the interview.

When applying this method, the following ethical requirements have been complied with: 
- a participant agreed to participate in an interview grounding on his/ her free will. In relation to this, the conditions have been discussed: a participant consents to be enquired for a particular period of time in a certain place on a specific topic and being clearly assured about confidentiality;

- the researcher had an advance provision that interview participants could change their minds at any time. To prevent this, the research goals have been repeated and confidentiality has been assured at the start of the interview.

The goal of the in-depth interview was to broadly discuss essential questions and also to investigate each of them quite in depth. To achieve this, the questions of content depiction and content obtaining have been used (see Tables 1-2) (Ritchie, Lewis, 2003). The questions of content depiction helped to formulate the aspects of problems which were important to a participant. The questions of content obtaining helped to design the details for investigation, which lied in each aspect, to obtain in-depth perception of an informant's point of view.

The content of the in-depth interview was constructed on the ground of the earlier conducted investigation, i.e. the data obtained during the questionnaire-based survey. In the course of application of this method, two factors which were the most engaging personnel in work have been underlined (favorable work conditions, financial incentive). The research sample comprised 12 informants.

\section{Table 1. Constructs of the questions for personnel engagement in work in terms of the factor FAVORABLE WORK CONDITIONS}

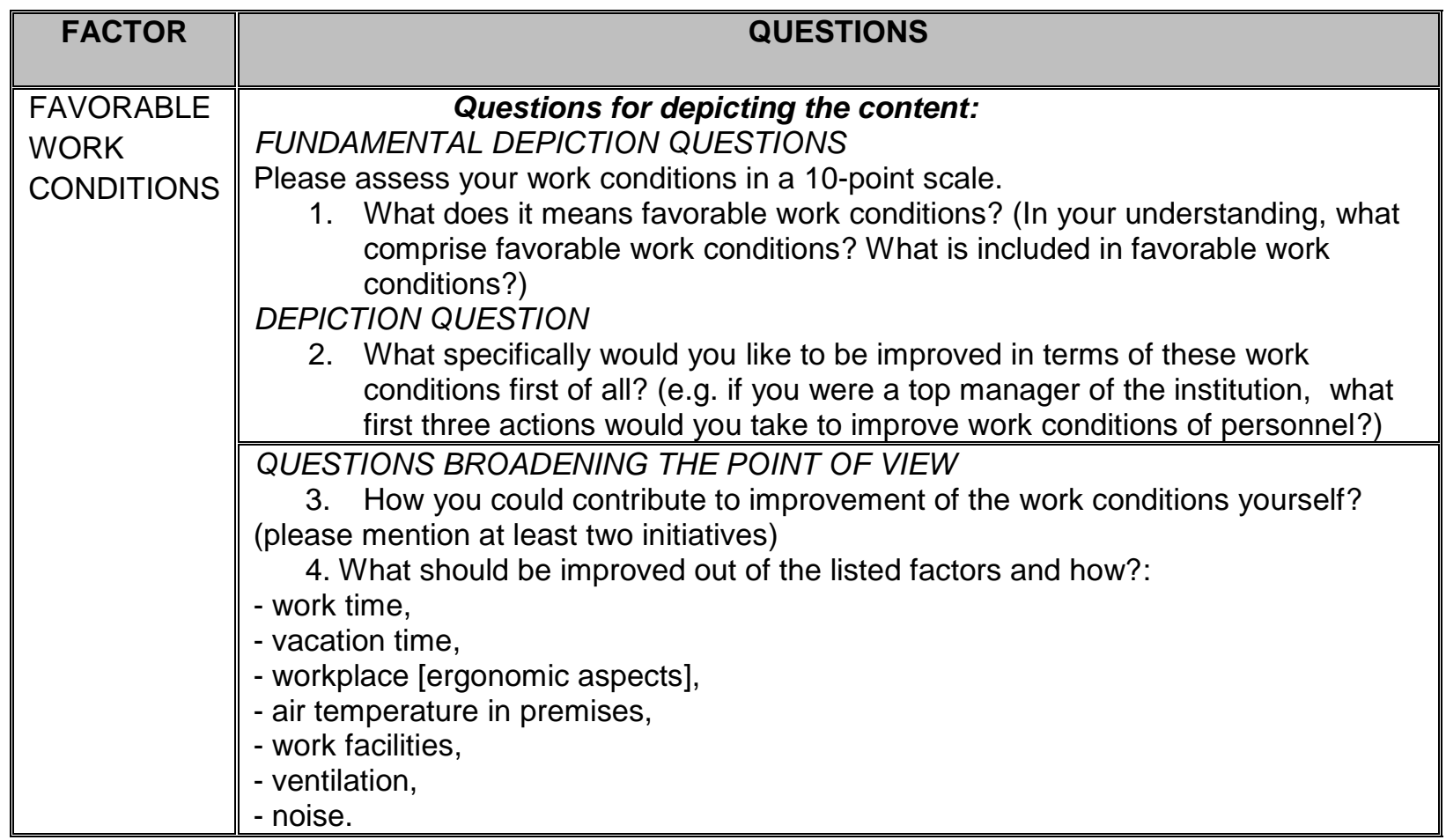


Table 2. Constructs of the questions for personnel engagement in work in terms of the factor FINANCIAL INCENTIVE

\begin{tabular}{|c|c|}
\hline FACTOR & QUESTIONS \\
\hline $\begin{array}{l}\text { FINANCIAL } \\
\text { INCENTIVE }\end{array}$ & $\begin{array}{l}\text { Questions for depicting the content: } \\
\text { FUNDAMENTAL DEPICTION QUESTIONS } \\
\text { Please assess the system of financial incentive at the institution while developing } \\
\text { prevention programs in a 10-point scale. } \\
\text { 1. Is the procedure of the salary payment for the services provided while } \\
\text { implementing prevention programs objective? (i.e. just for all); } \\
\text { DEPICTION QUESTION } \\
\text { 2. If it is not just, then what should be improved? } \\
\text { QUESTION BROADENING THE POINT OF VIEW } \\
\text { 3. If you were the top manager of the institution, what three actions would you } \\
\text { take to improve financial incentive aiming at personnel motivation in increasing } \\
\text { development of prevention programs? } \\
\text { QUESTIONS FOR OBTAINING THE CONTENT } \\
\text { 4. What work should be financially stimulated in your institution to increase } \\
\text { motivation and the work were more effective? } \\
\text { 5. What methods would motivate personnel to get financial incentive (e.g. } \\
\text { bonuses, supplement to salary etc.)? }\end{array}$ \\
\hline
\end{tabular}

The data analysis employed the content analysis method combining the types of analysis of the meanings and qualitative content analysis (Mayring, 2014). According to the methods of the mentioned authors, transcription of the data, depersonalization of the data have been done. In the current study, partial extracts were chosen to be displayed, without reflecting non-verbal interaction aspects. Answers of the respondents have been grouped according to semantic-lexical similarity. These groups of data have been named (nomination of the categories) by giving them an appropriate title.

\section{ANALYSIS OF THE DOMINATING FACTORS IN PERSONNEL ENGAGEMENT IN WORK}

After applying the Pareto principle, 20 percent of the eight factors point out the following two factors: favorable work conditions and financial incentive (see Table 3). 
Table 3. Distribution of personnel motivation factors (from the most important (1) to the least important (8)

\begin{tabular}{|c|c|c|c|}
\hline Group of factors & Factors & $\begin{array}{c}\text { Physicians } \\
(\mathrm{N}=35)\end{array}$ & $\begin{array}{l}\text { Nurses } \\
(\mathrm{N}=39)\end{array}$ \\
\hline \multirow{8}{*}{$\begin{array}{l}\text { Group of organizational } \\
\text { factors }\end{array}$} & Favorable work conditions & 1 & 1 \\
\hline & Financial incentive & 2 & 2 \\
\hline & $\begin{array}{l}\text { Acknowledgement of personal } \\
\text { performance }\end{array}$ & 3 & 4 \\
\hline & Provision of facilities for work & 4 & 3 \\
\hline & Flexible timetable of work & 5 & 5 \\
\hline & Optimal workload & 6 & 7 \\
\hline & $\begin{array}{l}\text { Provision of opportunities for self- } \\
\text { continuation }\end{array}$ & 7 & 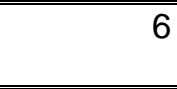 \\
\hline & Assurance of autonomy & 8 & 8 \\
\hline
\end{tabular}

Having rated the opinions of physicians and nurses, the data distributed as follows: personnel are mostly engaged in work being stimulated by good work conditions, financial incentive, acknowledgement of personal performance, provision of facilities, flexible timetable of working hours, optimal workload, opportunities for self-continuation, assurance of autonomy.

\section{ANALYSIS OF MANIFESTATION OF THE FACTORS ENGAGING PERSONNEL IN WORK}

Grounding on the investigation of the personnel rating their opinions, their engagement in work is mostly impacted by favorable work conditions and financial incentive.

Manifestation of the factor "favorable work conditions" in personnel engagement in work. The informants assessed their work conditions in a ten-point scale as good (8) (opinions distributed from 6 to 10).

To find out how to improve the work conditions, first of all, we focused on revealing how employees understood what it meant "favorable work conditions" to them. Personnel identify them with cozy physical environment, good relationships with co-workers, pleasant inner feeling, competent personnel and time distribution (Table 4).

\section{Table 4. Employees' opinions about favorable work conditions}

\begin{tabular}{|c|c|c|}
\hline Category & Sub-category & Illustrating statements \\
\hline \multirow[t]{2}{*}{$\begin{array}{l}\text { FAVORABLE } \\
\text { WORK } \\
\text { CONDITIONS }\end{array}$} & $\begin{array}{l}\text { Personal, cozy } \\
\text { physical } \\
\text { environment }\end{array}$ & $\begin{array}{l}\text { <to have a room >; <a room is renovated, spacious, bright }>\text {; <to } \\
\text { have a proper workplace>; <comfortable workplace, good lighting, } \\
\text { comfortable temperature, comfortable table, good equipment, } \\
\text { computer is necessary>; <to work in a room alone: you can come } \\
\text { earlier, work longer >; <environment surrounding you>; <provision of } \\
\text { all the facilities, means for your work. A room is tidy > }\end{array}$ \\
\hline & $\begin{array}{l}\text { Good } \\
\text { relationships with } \\
\text { co-workers }\end{array}$ & $\begin{array}{l}<\text { we work together with a nurse, we get on well }>\text {; < relationships } \\
\text { with personnel }>\text {; <the attitude of administration is very important }>\text {; } \\
<\text { first of all, very good microclimate of relationships. No divide } \\
\text { between physician, nurse and patient }>\text {; < }<\text { we all work together like }\end{array}$ \\
\hline
\end{tabular}




\begin{tabular}{|c|c|c|}
\hline \multirow{4}{*}{ 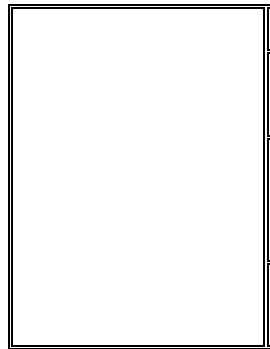 } & & one fist, one team >; <to have a good collective > \\
\hline & Inner satisfaction & $\begin{array}{l}\text { no stress to prepare for work }>\text {, <a person should do his/ her } \\
\text { favorite job }>\text {; }<\text { no tension at work }>\end{array}$ \\
\hline & $\begin{array}{l}\text { Competent } \\
\text { personnel }\end{array}$ & $\begin{array}{l}\text { first of all, competent personnel }>\text {; <must have required } \\
\text { qualification for their work }>\text {; <good personnel, i.e. knowing their } \\
\text { job }>\end{array}$ \\
\hline & Time & $\begin{array}{l}<\text { to have enough time to stay with a patient }>\text {; <to have no need to } \\
\text { hurry }>\text {. }\end{array}$ \\
\hline
\end{tabular}

Staff members were asked to list what specifically they would like to improved first of all in terms of work conditions. The opinions most focused on improvement of physical environment: they needed air-conditioning, separate rooms for procedures, physicians, a room for resting, some equipment, good lighting:

$<$ A room should have a procedural area, air-conditioning would be desired [38BA, 28OJ]>; $<$ To have more equipment [02AU]>; < To have what is related to my field of operations. To have equipment, ventilation of premises, facilities and means for work [23IR]>; <Provision with all facilities, means for work. A room is tidy [38IR] $>$; <To improve lighting, air-conditining in the summer time, a good computer [19KA] >; <Computers available to both nurse and physician, a room for work, a room for resting (on each floor) [43JA]>.

Several informants expressed their ideas on the need for good relationships with colleagues: $<$ Perhaps there is lack of meetings of personnel, get together not only during working hours. I would equip a separate room for personnel to have rest, which we need badly [11LI] ; <To have

good microclimate, to have team work [55SO] $>$; <l would like to have a better work ambiance

$[15 \mathrm{JU}]>$.

Moreover, employees suggest to improve the conditions related to time, i.e. they would like to allocate more time to a patient: <sufficient time to spend with a patient, e.g. $40 \mathrm{~min}$. [02AU]>; and they would like to attend training sessions: <unless training sessions would be arranged more often. It is very important for us, and we want and need to have them [02NE]>.

Since initiatives proposed by personnel are welcome at the organization, it is important to clarify how much employees are willing to contribute to improvement of favorable work conditions. To sum up the results, we can put it that personnel relate the improvement of conditions with the needs of patients (however, they do not relate this to their initiative):

$<$ Clients who are waiting behind the door could watch relaxing video clips or listen to the music. Or listen to information, e.g. on diabetes, nutrition, exercises to avoid problems [38BA]>; $<$ prolongation of visitation [28OJ] $>$.

Another suggestion on how they could contribute to improvement of the conditions is related to keeping comfortable temperature in premises and having short breaks:

$<$ to have short breaks. This is mental work, with people. I suppose, a person cannot work at seven p.m. at such a pace because the brain does not work that fact anymore [15JU] $>;<$ would make a break official [28OJ]>; <ventilation of premises [23IR] [55SO] [43JA]>.

To sum up, we can state that the informants do not want to contribute to improvement of the relationships with co-workers themselves to ensure better inner self-satisfaction; they do not search for possibilities to effectively use the time. They transfer these important to them 
processes to the domain of others' responsibility. They suggest how others could improve conditions for patients or take responsibility for ventilation of premises only.

Manifestation of the factor "financial incentive" for personnel involvement in work. Personnel assess financial incentive in their organization as good (8) (opinions varied from 7 to 10).

Moreover, it was aimed at finding out about the current situation, whether the existing to present situation of payment for services provided in the framework of preventive programs was objective, just. Having analyzed opinions of the informants, we can put it that the assessment is ambiguous: some state that they "do not feel" financial incentive, to others everything is objective and just.

Individuals stating that the procedure of payment for the services provided in the framework of prevention programs is unjust, argue grounding on their large personal contribution or lack of clarity:

$<$ personally work as much as possible. If they say that salary will be reduced, l'll give up because I cannot do more. I do not feel the supplement to the salary and I think that this is unjust [38BA]>; <There is lack of transparency. I need concreteness. To name specifically for what, how much, under what conditions you will give us in order we could be aware how much we received for what [15JU] >; <I am not aware how many percent I get as a supplement. I don't know [09AU]>; <lt's hard to say. We receive some kind of a supplement to our salaries, for implementation of preventive programs, but it is not very clear how it is calculated, what percentage comes from these preventive programs. Therefore, clarity would contribute to better understanding [13AM] >; < suppose everyone needs specific explanation to bring better understanding to each person, to simply be aware about it [37IR]>.

Individuals stating that the procedure of payment for services provided in the framework of prevention programs is just argue grounding on its clarity, suggestion to increase the number of funded programs and trust in managers of the institution:

$<$ am aware what I receive for [02NE] $>$; $<$ To increase the number of funded programs [11LI] $>$;

$<$ I would suppose that it's just. What I do, I receive. It seems to me that I do twice more but receive the same, however, it doesn't mean that I should receive higher payment. I simply respect

heads of the institution very much. If they think that my salary must be exactly what I receive, I suppose this is quite good $[23 \mathrm{IR}]>;<$ suppose that the current order of the payment is objective and just [55SO]>.

Having clarified the existing situation, employees were offered to name the ways of financial incentive to improve justice, transparency, to motivate personnel implement preventive programs themselves. At the start, responses of patients were rejected as a non-objective factor: <If you ask patients to provide their responses, this will be non-objective [38BA]>.

The ways suggested by personnel are related to a clear formula of funding according to which they could see the result of their contribution; suggestion that all preventive programs were funded; number of patients, age, gender; priorities of specific research/ programs and their amounts; complex approach to personnel (from his/ her personal traits to loyalty to the institution) (Table 5). 


\section{Table 5. Ways suggested by personnel to improve financial incentive}

\begin{tabular}{|c|c|}
\hline $\begin{array}{l}\text { Means of financial } \\
\text { incentive }\end{array}$ & Illustrating statements \\
\hline $\begin{array}{l}\text { Clear formula of funding } \\
\text { which could show the result } \\
\text { of the contribution }\end{array}$ & $\begin{array}{l}<\text { We have no possibility to check. We don't know how much we do, how } \\
\text { much for what we get [43JA] }>\text {; }<\text { Clarity of what you have done because } \\
\text { we do not accurately calculate everything. Just needed that they } \\
\text { presented how much I did per month or quarter for the programs and } \\
\text { clearly presented how much they pay me for these programs, how many } \\
\text { percent of income. Clarity expressed in numbers }[13 \mathrm{AM}]>;<\text { That each } \\
\text { person knew how much one receives for each program }[28 \mathrm{OJ}]>;<\text { That } \\
\text { this incentive were just. You will get for what you have done. When there } \\
\text { is no such transparency, people are not so much interested [37IR] }>\end{array}$ \\
\hline $\begin{array}{l}\text { Payment for all preventive } \\
\text { programs }\end{array}$ & $\begin{array}{l}<\text { would like to have received payment for each program [19KA] [11LI] } \\
[01 \mathrm{IR}] 43 \mathrm{JA}]>\end{array}$ \\
\hline $\begin{array}{l}\text { Related to the number of } \\
\text { patients }\end{array}$ & $\begin{array}{l}<\text { For all programs and number of served patients per day }[11 \mathrm{LI}]>;<\mathrm{tt} \\
\text { would be more effective if we saw how many enlisted people, their } \\
\text { amount }[28 \mathrm{OJ}]>\end{array}$ \\
\hline $\begin{array}{l}\text { Related to the age and } \\
\text { gender of patients }\end{array}$ & $\begin{array}{l}\text { <lt is more difficult with elder people, they need more visits and there is } \\
\text { little of preventive programs because they are no longer prescribed to } \\
\text { them. They could pay for this a little bit more if a patient, for instance, is } \\
\text { over sixty [02NE]; <There could be more women, too. They could be } \\
\text { invited. The more of them, the higher our salary [23IR]> }\end{array}$ \\
\hline $\begin{array}{l}\text { Related to priorities of } \\
\text { specific research/ programs } \\
\text { and their amount }\end{array}$ & $\begin{array}{l}\text { <First of all, incentive should be for echoscopic examination. Because } \\
\text { perhaps none of physicians in the world do this for free. A certain } \\
\text { payment should be based on the number of performed examinations, for } \\
\text { sure [23IR]>; <Maybe your community, your neighborhood vaccination } \\
\text { averages. Maybe some incentive option could be introduced. Maye if } \\
\text { there are many children in one's own position, how many vaccinated } \\
\text { individuals are in your neighborhood in compliance with the vaccination } \\
\text { calendar of the Republic of Lithuania. It depends how you manage it as } \\
\text { a professional, how your nurse manages to professionally convince } \\
\text { parents to allow scientifically reasoned vaccination and achieve certain } \\
\text { results. This is health promotion for community, a step forward to a } \\
\text { healthier society [13AM]> }\end{array}$ \\
\hline $\begin{array}{l}\text { Complex } \\
\text { personnel (from persoach to } \\
\text { traits to loyalty to the } \\
\text { institution) }\end{array}$ & $\begin{array}{l}<\text { Each employee should be seen and assessed individually, to assess } \\
\text { one's qualification, honesty, morality, workload [55SO]>; <Perhaps } \\
\text { loyalty to the institution }[13 \mathrm{AM}]>;<\text { delivery of lectures for the community } \\
\text { one or few times per year. Such is professional activeness [13AM]>; } \\
<\text { Sharing both success and failure when treating one or another } \\
\text { disease. I suppose there could be incentive for such things because } \\
\text { now it is compulsory [13AM]> }\end{array}$ \\
\hline
\end{tabular}

In the sub-category "clear formula of funding which could show the result of the contribution", the informants focus on the idea that such system would be not only more transparent: <To make this incentive just. You'll receive for what you've done. When there is no such transparency, people are not so much interested [37IR]>; but in general they express the idea that such one should 
exist in the organization: <we have no possibility to check. We don't know how much we do, how much for what we get [43JA]>. Informants want to see the constituent parts of the formula comprising calculations for all prevention programs: <l would like to be paid for each program [19KA] [11LI] [01IR] 43JA]>, relating them to the number, age, gender of patient:

$<$ For all programs and served patients per day [11LI]; <It is more difficult with elder people, they need more visits and there is little of preventive programs because they are no longer prescribed to them. They could pay for this a little bit more if a patient, for instance, is over sixty $[02 N E] ;<$ There could be more women, too. They could be invited. The more of them, the higher our salary $[23 \mid R]>$.

In the sub-category "complex approach to personnel (from one's personal traits to loyalty to the institution)", the opinion of the informants focuses on assessment of an employee as a personality: one's honesty, morality, loyalty to the institution etc.: < each employee should be seen and assessed individually, to assess one's qualification, honesty, morality, workload [55SO]>; <Perhaps loyalty to the institution [13AM] $>$.

Moreover, there were those who stated that none of the ways would help anymore because an informant works at his/ her maximum capacity: <l do everything maximally and they will not squeeze anything out of me anymore [38BA]>.

Other means of financial incentive are related to bonuses, supplements, additional day-off, funded qualification development (Table 6).

\section{Table 6. Means of financial incentive of personnel}

\begin{tabular}{|c|c|}
\hline $\begin{array}{l}\text { Means of financial } \\
\text { incentive }\end{array}$ & Illustrating statements \\
\hline $\begin{array}{l}\text { Bonuses } \\
\text { supplements to the } \\
\text { salary }\end{array}$ & $\begin{array}{l}<\text { We would like to get bonuses, then at least we would know that } \\
\text { administration value us. This would be the most objective assessment of my } \\
\text { job [38BA] }>\text {; <Personally I would want to get supplements to my salary. The } \\
\text { best way to solve it financially [15JU]>; <Each incentive is very obviously } \\
\text { visible. Clear, that always a bonus or supplement to my salary will be the } \\
\text { largest incentive, and this would improve the situation very much [11LI]>; } \\
\text { <supplement to the salary [23IR] [55SO] [01IR] [37IR] [28OJ]> }\end{array}$ \\
\hline Additional day-off & $\begin{array}{l}<\text { Personally I would like to get a day-off }[43 \mathrm{JA}]>;<\text { suppose, additional day- } \\
\text { offs would strongly motivate or day-offs on the desired time which is suitable } \\
\text { for you [13AM] }>;<\text { If there were an additional day-off, I would be pleased to use } \\
\text { to solve my own problems }[28 \mathrm{OJ}]>\end{array}$ \\
\hline $\begin{array}{l}\text { Funded qualification } \\
\text { development }\end{array}$ & $\begin{array}{l}<\text { Such as funding qualification development. And psychological motivation is } \\
\text { very good [13AM] }>\end{array}$ \\
\hline
\end{tabular}

It can be stated that a traditional point of view towards engagement in work (when directly received payment is the main source of incentive) dominates in the institution the most. When forming the policy of personnel, the institution should regard the performance results because currently the principle to relate salaries of personnel to their performance results is not complied with. 
Grounding on the assumptions of the research results obtained by Viningiene (2014), it can be stated that such focusing on financial incentive allows deciding about the personnel's attitude towards responsibility (the author has found out that "for those individuals who take responsibility at work the increase of salary, bonuses and other material incentives had no high significance on their performance results" (p. 165).

To sum up, financial incentive is very important to personnel. When assessing the current situation related to implementation of prevention programs, employees argue grounding on their personal contribution. To some employees the contribution is financially justly and objectively stimulated, to others there is lack of clarity and they "do not feel" any incentive.

\section{CONCLUSIONS}

Having analyzed manifestation of the factors of personnel engagement in work, we can have the following:

1. Favorable work conditions motivate personnel the most. Employees identify them with cozy physical environment, good relationships with co-workers, good inner feeling, competent personnel and the factor of time. Grounding on the research data, we can state that the informants do not want to contribute to improvement of the conditions, to ensure better inner self-satisfaction themselves, they do not search for possibilities how they could effectively use the time.

2. Financial incentive as a factor determining engagement in work has been attributed to the second place, as the rating suggests. Personnel would be motivated to implement prevention programs more effectively not only having provided means of incentive calculated on the basis of clear/ objective funding (bonuses, supplements to salary, additional day-offs, qualification development), but also the relation of dependence of their amount related to the number, age, gender of patients, prioritization of prevention programs, loyalty to the institution, other professional activeness.

\section{References}

BENSON, S.G., DUNDIS, S.P. (2003). Understanding and Motivating Health Care Employees: Integrating Maslow's Hierarchy of Needs, Training and Technology. J Nurs Manag., 11: 315-320. 10.1046/j.1365-2834.2003.00409.x.

BURNS, L., BRADLEY, E. AND WEINER, B. (2011). Shortell and Kaluzny's Healthcare Management: Organization Design and Behavior. Cengage Learning.

BYRNE, M. (2006). The Implications of Herzberg's "Motivation-Hygiene" Theory for Management in the Irish Health Sector. Health Care Manag., 25: 4-11. https://doi.org/10.1097/00126450-20060100000002

DEMYEN, S., POPA, I. L. (2015). Human Resource Performance Assessment and Disparities Regarding Reward System - Are They Determinants of the Emigration Phenomena? The Case of Romania - A View from the Top. International Journal of Social Sciences, Vol. IV(1): 1-13. https://doi.org/10.20472/SS2015.4.1.001

FRANCO, L. M., BENNETT, S., KANFER, R., STUBBLEBINE, P. (2004). Determinants and Consequences of Health Worker Motivation in Hospitals in Jordan and Georgia. Soc Sci Med., 58: 343-355. 10.1016/S0277-9536(03)00203-X. 
GREEN PAPER ON THE EUROPEAN WORKFORCE FOR HEALTH (2008). European Commission, Brussels, 10.12.2008 COM (2008) 725 final. http://eur-lex.europa.eu/legalcontent/LT/TXT/PDF/?uri=CELEX:52008DC0725\&from $=$ LT

HEJDUKOVÁ, P., KUREKOVÁ, L. (2017). Performance and sustainable of healthcare systems and approaches to its measuring and evaluating. International Journal of Social Sciences, Vol. VI(2): 32-43. https://doi.org/10.20472/SS2017.6.2.003

ISMAIL, K., FORD, D. L. (2009). Organizational Leadership in Central Asia and the Caucasus Research Considerations and Direction. Asia Pac J Manage, 27: 321-340. https://doi.org/10.1007/s10490-0089130-3

JOHNSON, J. A. (2017). Health Organizations: Theory, Behavior, and Development. Jones \& Bartlett Learning.

KARNIELI-MILLER, O., TAYLOR, A., INUI, T. S., IVY, S. S., FRANKEL, R. M. (2011). Understanding Values in a Large Health Care Organization through Work-Life Narratives of High-Performing Employees. Rambam Maimonides Med J. Oct; 2(4), 1-14. https://doi.org/10.5041/RMMJ.10062

$\mathrm{KOCH}$, R. (2011). The 80/20 Principle: The Secret of Achieving More with Less, 2nd ed., London: Nicholas Brealey Publishing, $289 \mathrm{p}$.

KONTODIMOPOULOS, N., PALEOLOGOU, V., NIAKAS, D. (2009). Identifying Important Motivational Factors for Professionals in Greek Hospitals. BMC Health Serv Res., 9: 164-10.1186/1472-6963-9164.

LAMBROU, P., KONTODIMOPOULOS, N., NIAKAS, D. (2010). Motivation and Job Satisfaction among Medical and Nursing Staff in a Cyprus Public General Hospital. Human Resources for Health, 8:26, p. 2-9. DOI: 10.1186/1478-4491-8-26.

LAUBACH, W., FISCHBECK, S. (2007). Job Satisfaction and the Work Situation of Physicians: a Survey at a German University Hospital. Int J Public Health., 52: 54-59. 10.1007/s00038-006-5021-x.

LAW ON PUBLIC HEALTH CARE OF THE REPUBLIC OF LITHUANIA (2002). Valstybès žinios, 1993, No. 56-2225.

LEDLOW, G. R. AND STEPHENS, J. H. (2017). Leadership for Health Professionals: Theory, Skills, and Applications. Jones \& Bartlett Learning.

LITHUANIA'S PROGRESS STRATEGY "LITHUANIA 2030" (2012). The Seimas of the Republic of Lithuania on 2012 May 15th the ruling No. XI-2015, Valstybės žinios, 2012, No. 61-3050.

MANONGI, R.N., MARCHANT, T.C., BYGBJERG, I.C. (2006). Improving Motivation among Primary Health Care Workers in Tanzania: a Health Worker Perspective. Hum Resour Health, 4: 6-10.1186/14784491-4-6.

MANZOOR, Q. A. (2012). Impact of Employees Motivation on Organizational Effectiveness. Business Management and Strategy, 3 (1): 1-12.

MAYRING, P. (2014). Qualitative Content Analysis: Theoretical Foundation, Basic Procedures and Software Solution: Monograph, Klagenfurt, Austria, 143 p. http://nbn-resolving.de/urn:nbn:de:0168ssoar-395173

MINER, J. B. (2003). The Rated Importance, Scientific Validity, and Practical Usefulness of Organizational Behavior, Academy of Management Learning \& Education, Vol. 2, No. 3, p. 250-268. https://doi.org/10.5465/amle.2003.10932132 
NAQVI, S. A. H., HASHMI, M. A., RAZA, S. A., ZEESHAN, A. AND SHAIKH, A. (2011). Impact of Supportive Leadership and Organizational Learning Culture as a Moderator on the Relationship of Psychological Empowerment and Organizational Commitment. Australian Journal of Business and $\begin{array}{llllll}\text { Management Research, } & \text { Vol. } & \text { No. } & \text { 65-71. }\end{array}$ http://www.ajbmr.com/articlepdf/AJBMR 18 10i1n8a8.pdf

OLDEN, P. C. (2011). Management of Healthcare Organizations: An Introduction. Health Administration Press.

ON EFFECTIVE, ACCESSIBLE AND RESILIENT HEALTH SYSTEMS (2014). European Commission, Communication from the Commission, Brussels, 4.4.2014 COM (2014) 215 final. http://ec.europa.eu/health//sites/health/files/systems performance assessment/docs/com2014 215 fin al en.pdf

RITCHIE, J., LEWIS, J. (2003). Qualitative Research Practice: a Guide for Social Science Students and Researchers, Trowbridge, Wiltshire, Great Britain: The Cromwell Press Ltd, 349 p. https://mthoyibi.files.wordpress.com/2011/10/qualitative-research-practice a-quide-for-socialscience-students-and-researchers jane-ritchie-and-jane-lewis-eds 20031.pdf

SHARMA, M., BHATI, M. (2017). The Role of Organizational Factors of Empowerment and Motivation in Enhancing Employees' Commitment in Indian Automotive Industry. Universal Journal of Industrial and Business Management, 5(3): p. 29-37. DOI: 10.13189/ujibm.2017.050301.

TALJUNAITE, M. (2012). Factors Stabilizing Doctors Careers in Lithuania. Philosophy. Sociology, No. 23 (2), p. 154-163. http://mokslozurnalai.Imaleidykla.It/publ/0235-7186/2012/2/154-163.pdf

UNTERWEGER, M., IMHOF, S., MOHR, H., RÖMPLER, M., KUBIK-HUCH, R. A. (2007). Which Factors Influence Job Satisfaction and Motivation in an Institute of Radiology?. Praxis (Bern 1994). 96: 12991306. $10.1024 / 1661-8157.96 .35 .1299$

VININGIENE, D. (2014). Employees Relationship between Work Motivation and Job Satisfaction. Regional Formation and Development studies, Vol. 6, No. 1, p. 161-170. http://journals.ku.It/index.php/RFDS/article/view/544/433

YANG, I. (2006). Jeong Exchange and Collective Leadership in Korean Organizations. Asia Pacific Journal of Management, Springer, vol. 23(3), p. 283-298. https://doi.org/10.1007/s10490-006-9003-6

YAZANI, B. O., YAGHOUBI, N. M, GIRI, E. S. (2011). Factors Affecting the Empowerment of Employees: An Empirical Study, European Journal of Social Science, 20(2), p. 267-274.

ZAPTORIUS, J. (2007). Creation of Employee Motivation System and Its Theoretical Analysis. Philosophy. Sociology, No. 18, (4), p. 105-117. http://mokslozurnalai.Imaleidykla.It/publ/0235-7186/2007/4/105117.pdf 